\title{
A MULTIMODAL VIEW OF LATE MEDIEVAL RHETORIC: THE CASE OF THE WHITE ROSE OF YORK ${ }^{1}$
}

\begin{abstract}
The aim of the present paper is to contribute to a better understanding of the role of heraldry, in particular of para-heraldic devices known as "badges", in 15th-century England. The case chosen for examination is that of the white rose, one of the major badges of Edward IV.

The data consists of four contemporary texts in which Edward is referred to as the "rose", analysed against the background of the use of the white rose of York as a heraldic device. This includes surviving artefacts ranging from effigies to stained glass to seals and manuscript illuminations, as well as contemporary descriptions and depictions of those artefacts.

Using the methodological apparatus of cognitive linguistics, specifically the multimodal metaphor and metonymy analysis, the author examines the interplay between language and heraldry. The results show that while the primary function of the white rose and of other badges employed by Edward IV was to emphasize his heritage and thus invite a metonymic reading, the badge inspired other, metaphorical readings, which were employed rhetorically by his supporters. In this context, the concept of the badge may be reinterpreted as a metaphtonymy.

The analysis supports the view of heraldry as an integral element of medieval society. From a semiotic perspective, heraldry should be seen as a dynamic system that could be exploited creatively to suit the needs of its users, which in turn corresponds to the dynamic theory of metaphor.

Keywords: heraldic badge, metaphor, metonymy, rhetoric, Edward IV.
\end{abstract}

\section{Introduction}

Although nowadays heraldry is of relatively little significance, being limited largely to the scope of interest of armigerous families, historians, historical re-enactment groups, and wargaming communities, its impact on medieval society was much greater. Contrary to common belief, coats of arms were not restricted to the nobility; they were used by both men and 
women who belonged to various social strata, from the nobility to clergy, to townsfolk, to peasants, and by the institutions that represented them such as cities, guilds, brotherhoods, abbeys, etc. (see Pastoureau, 2004, p. 222). While, admittedly, signalling the identity of the bearer of a coat of arms was the primary function of heraldry, ${ }^{2}$ it was not the only function. Heraldic devices were also used as markers of group identity (both in war and peace), they communicated social status and aspirations, and they could also serve as a means of conveying specific political messages (see Hiltmann, 2018). The means through which heraldic meaning was communicated included the use of images, sculpture, architecture, language, and pantomime, as well as various combinations of the above. Thus, heraldry may be regarded as an integral part of the medieval landscape (both physical and mental) much like traffic signs today.

While there is abundant literature on heraldry, most works have traditionally described it from the perspective of modern times (Boutell, 1864; Rothery, [1915] 1985; Wagner, 1972, among others). It was only studies like Pastoureau (1993, 2004) and more recently Coss and Keen (2002), Hablot (2006), and Hiltmann and Hablot (2018) that have brought a better understanding of the role of heraldry in the Middle Ages.

The dynamic nature of the heraldic system is clearly visible in the development during the late Middle Ages of para-heraldic devices nowadays called badges. In general, what distinguished them from coats of arms was that they were consciously adopted rather than inherited; they appeared in a wider variety of forms and situations than coats of arms; they were not (or not only) used by their owners, but rather by their retainers and followers; and finally, their function was not limited to markers of identity, but involved also serving as signs of prestige, allegiance, or ownership. Having said that, it needs to be stressed that the picture of heraldry in the Middle Ages is much more complex. Firstly, there was a considerable overlap between badges and coats of arms, the latter in many cases being the source of the former, which in turn meant that badges could also be inherited (see Siddons, 2009a, pp. 6-9). Secondly, while in some cases badges seem to have been worn only by the owner's followers, there are artefacts that prove that they could also adorn the owner. ${ }^{3}$ Finally, there are a number of cases in which a coat of arms was modified or changed in order to suit a particular purpose. ${ }^{4}$

Badges witnessed their heyday during the late Middle Ages, when armigers often chose to quarter their arms with those to which they were entitled through descent, marriage, or office. The resulting complex armorial designs emphasised prestige at the expense of clarity of display. This in 
turn reduced their usability on the battlefield (cf. Pastoureau, 1993, pp. 218219). ${ }^{5}$ The badge could be seen as a remedy, or a (successful) bid to have the heraldic cake and eat it too. From a semiotic perspective, then, heraldry should not be seen as a uniform and rigid system, but rather as a dynamic construct which served particular purposes and which was flexible enough to develop an offshoot that took over functions that its mainstream form could no longer perform.

The present paper focuses on late medieval English badges. This issue was studied, among others, by Fox-Davies (1907), Wagner (1955), London (1956) and Blair and Delamer (1988), yet the benchmark has been set by the monumental three-volume study by Siddons (2009a), (2009b), (2009c), (2009d). ${ }^{6}$ Since then, a number of works devoted to the role of heraldry (and badges in particular) in social and martial display have been published (see Jones, 2010; Ward, 2016, among others). However, there is still room for a more semiotically oriented approach to late medieval badges. In view of the author of the present thesis, the methodological apparatus of cognitive linguistics offers tools for investigating the interplay between verbal and visual rhetoric.

\section{Cognitive linguistics}

Cognitive linguistics emerged in the 1970s and 1980s from the research of Ronald Langacker, George Lakoff, Charles Fillmore and Leonard Talmy, who all questioned a number of "dogmas" of mainstream linguistics of the period. Those included, among others, the widely accepted dichotomies of objective vs. subjective knowledge, linguistic vs. encyclopedic knowledge, linguistic vs. conceptual structures, literal vs. figurative language and synchronic vs. diachronic linguistics (see Nerlich \& Clarke, 2007, pp. 590-591). While cognitive linguistics should be seen as "a cluster of broadly compatible approaches" (Geeraerts \& Cuyckens, 2007, p. 3), rather than a single uniform theory, there are some basic tenets to which most cognitive linguists subscribe. They include, among others, the appreciation of the role of cognition in language, central position of meaning and the adoption of the usage-based approach to language (see Geeraerts, 2010, p. 182).

Among the theoretical frameworks developed by cognitive linguists, the one of greatest interest in the context of the present paper is Conceptual Metaphor Theory (CMT). It dates back to the seminal study by George Lakoff and Mark Johnson (1980), in which they argue that metaphor is not (merely) a rhetorical device, but an important cognitive mechanism that 
helps us understand the world around us. The authors attach a similar value to metonymy, whose study - while originally lagging behind research on metaphor - has flourished since the late 1980s (see Lakoff \& Turner, 1989; Langacker, 1993; Panther \& Radden, 1999; Dirven \& Pörings, 2002, among others). There have also been studies devoted to the analysis of the interaction between metaphor and metonymy, initiated by Goossens (1990), who coined the term "metaphtonymy" to describe this phenomenon.

More recent developments address issues raised by some of the critics of CMT. For example, in response to the observation that despite its claim to encompass cognition in general, the theory is based only on verbal data, a number of cognitive linguists have begun to study pictorial, gestural, and multimodal instantiations of metaphor and metonymy in various discourse settings (Forceville \& Urios-Aparisi, 2009; Forceville, 2010; Cienki, 2013, among others). Multimodality can be understood either as "a property of a certain text that draws on more than one mode" or as a "perspective" that takes into account the multifaceted nature of communication (Tseronis \& Forceville, 2017, p. 5). The latter approach corresponds to the observation that multimodality should be perceived as "always having been the norm" (Bateman et al., 2017, p. 15). Thus, while interest in the issue is recent (see e.g. Jewitt et al. 2016; Bateman et al. 2017) the phenomenon itself is not, which is crucial in the context of the present study.

Another point of criticism targeted at CMT is that the pendulum of metaphor research swung too close to its biological extreme, which has been countered by the acknowledgement of the culture-specific aspects of conceptual metaphors (see Kövecses, 2010). This in turn has led to the development of a more dynamic approach that views metaphor as a process that takes place in discourse (Müller, 2008; Kolter et al., 2012). Thus, Müller (2008) introduces the notion of "degrees of metaphoricity", which divides metaphors into "sleeping" and "waking" rather than "dead" and "alive". Importantly, this distinction does not rely on the properties of a metaphorical expression, but rather on the context of its use. To put it differently, even conventional metaphors possess potential that can be "awakened" in a particular situation. The degree of activation of a metaphorical expression can be measured by the number of "metaphoricity indicators", which include "verbal elaboration, specification, semantic opposition, syntactic integration, or coexpressions of metaphor in a cooccurring modality such as gestures and pictures" (Müller, 2008, p. 198).

A different answer to the need for a more dynamic approach to metaphorical language was given by Fauconnier and Turner (e.g. 1995, 2002), who developed the theory of conceptual blending. Rather than seeing one 
concept in terms of another, in this theory relevant information from the two is dynamically integrated into a blend activated in the mind of the language user. The present study seeks to apply the above-described developments to the study of the white rose, one of the principal badges of the House of York and of Edward IV in particular.

\section{The white rose of York}

An heraldic rose was depicted in stylised form, as if seen from above. It usually consisted of a yellow or gold central disc (which was sometimes sprinkled with small circles representing the stamen) surrounded by five slightly concave petals, to which in the later Middle Ages were often added one or two outer five-petal rows. From underneath the petals were visible the narrow tips of five green, leaflike sepals (see Boutell, 1864, p. 75; Rothery, [1915]1985, p. 181; see also Fig. 1).

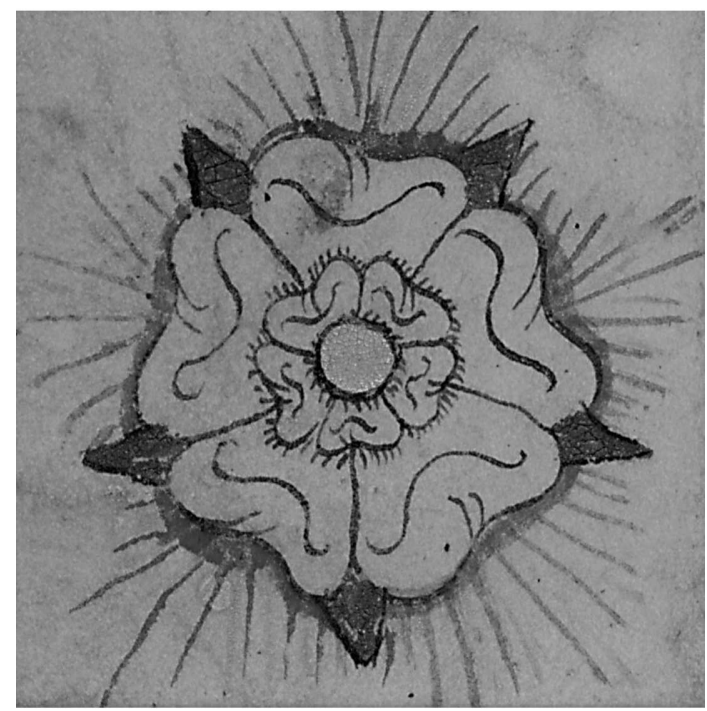

Figure 1. An heraldic rose (the white rose of York) taken from FLP MS Lewis E 201 (public domain)

The origins of the white rose as an heraldic badge of the House of York are not certain. Evidence supporting its use by the first two dukes of York is inconclusive (Siddons, 2009b, pp. 216, 218). In fact, there are two contemporary manuscripts, namely Digby 82 and BL, Add. 18268A, which suggest a different source. The former is a list of badges of the Duke 


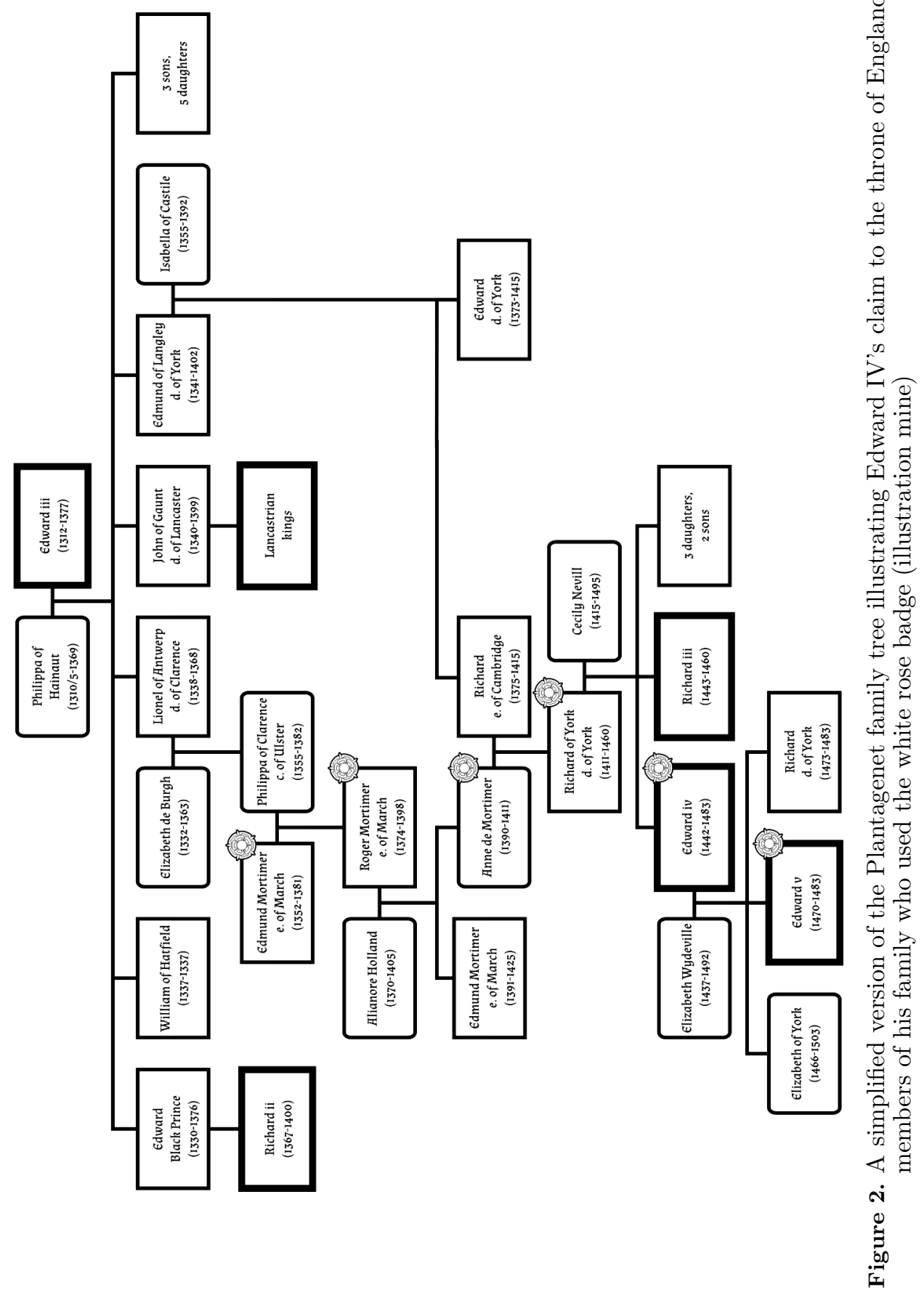


of York, recorded before 1460, according to which the white rose is borne "by the Castle of Clyfford" (as cited in Ellis, 1814, p. 226). The latter, a pedigree roll of Edward IV compiled after his accession, ascribes the badge in question to the Mortimer family. There is no real discrepancy between the two accounts, as the castle of Clifford, Herefordshire, was granted to Roger Mortimer, the second Earl of March, in 1356 (Rickard, 2002, p. 239). ${ }^{7}$ Roger's son, Edmund, married Philippa, the daughter of Lionel of Antwerp (the third son of Edward III). Their son, Roger (fourth Earl of March), in turn fathered Anne Mortimer, who married Richard, Earl of Cambridge (the younger son of Edmund of Langley, Edward III's fifth son and the first Duke of York). When Anne and Richard's son, Richard, third Duke of York claimed the throne of England in 1460, he used his Mortimer descent as a decisive argument (Griffiths, 1981, p. 867), since it traced back to Edward III's third son and thus was senior to that of Henry VI, who was a great-grandson of John of Gaunt, the fourth son of Edward III (see Fig. 2).

As for the rose, there is no indication how it had become attached to the castle of Clifford. It is tempting to link it to Henry II's mistress, "Fair Rosamond", who had been described as the daughter of Walter de Clifford at least since the late thirteenth century (Archer, 1887). Unfortunately, there is no evidence to advance this claim beyond speculation. Nor do we know whether the rose was originally white. The fragmentary data concerning the Mortimer family in the form of the last will of Edmund, Roger's son, reveal the use of red and gold roses only (as cited in Nichols, 1780, pp. 108, 112-113). It is possible that different members of the family used roses of different hues. It is also possible that it was Richard of York who chose the white colour for his rose in order to match it with two of his other principal badges, the white falcon and the lion of March. ${ }^{8}$ What is beyond doubt is that by the second half of the fifteenth century, the rose had become white and was regarded as part of the Mortimer heritage of the House of York. It was used as a badge by Richard of York and the subsequent Yorkist kings (Siddons, 2009b, pp. 218-220). Yet the bulk of evidence concerning the white rose of York can be attributed to Edward IV. This is hardly surprising, given the fact that unlike his father, he did win the throne, and unlike his son and younger brother, he held it for more than two decades. Thus, he had the means and opportunity to promote the imagery of his choice.

Most of the ten or so badges Edward IV employed consistently, each of which deserves a separate account, had been inherited from Edward III or his descendants (see Siddons, 2009b, pp. 7-8). Interestingly, the only badges designed by or for Edward IV were what might be described as blends (cf. Fauconnier \& Turner, 2002) of the white rose with another 


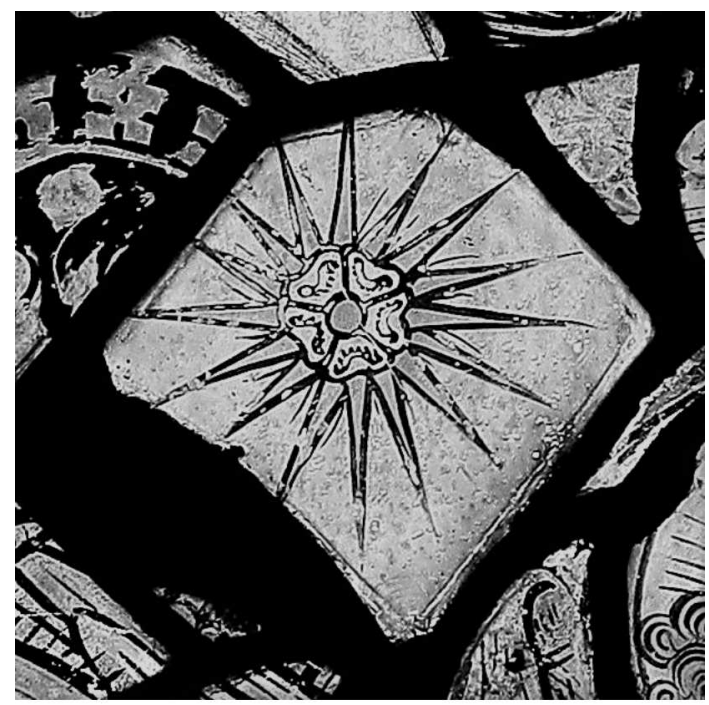

Figure 3. A rose en-soleil from a late fifteenth-century window at All Saints church, Bale, Norfolk (photograph by Mike Dixon)

Yorkist badge. Those were the white rose "en-soleil" - that is, superimposed on a sun whose rays project from underneath (see Fig. 3), and the white rose within a fetterlock..$^{9}$ As is the case with other badges, contemporary sources do not explain the meaning of the two. We can only draw inferences on the basis of what contemporaries knew about the emblems in question. Thus, in the former case, Edward IV probably chose to support his rose-signalled Mortimer claim with the sun, one of the favourite badges of Richard II, who was presented by the Yorkist propaganda as the last legitimate king before the Lancastrian usurpation. ${ }^{10}$ As far as the other instance of the complex badge is concerned, the rose took the place traditionally occupied by the white falcon. The white falcon within a golden fetterlock, which came from the dukes of York, was one of the favourite badges of Edward's father, Richard (London, 1956, pp. 21-24; Siddons, 2009b, pp. 99-100, 104-106). In a sense, then, Edward replaced his father's falcon with his rose within the fetterlock of York, assuming his place as the head of the family.

Whatever the precise interpretations of the above badges might be, the fact that the white rose is featured both on its own and in combination suggests it was of special significance to Edward IV. This is also evidenced by the richness of data comprising surviving artefacts as well as contemporary depictions and descriptions of artefacts relating to the use of the badge in its various forms. A detailed account of the use of the white rose of York can be 
found in Siddons (2009a, 2009b). Given the obvious space limitations, the present study will look into the major forms of display, with a focus on those most relevant to the analysis. Thus, items containing the badge ranged from those made for Edward's private use to those displayed by his household or by his subjects, and from exquisite expensive objects to those made of cheap material and produced on a mass scale. In particular, among Edward IV's private possessions decorated with roses, we can find bed furnishings and illuminated books, one of Edward IV's weaknesses (Backhouse, 1999). They also feature in other genres such as patent letters and pedigree rolls (Siddons, 2009a, p. 151), as well as on his royal seals (Birch, 1887, pp. 35-38). Roses were struck on Edward IV's coins and embroidered on his banners; they were also worn by his followers as items made of cloth or lead alloy, or as collars distributed among his courtiers and prominent supporters (see Gairdner, 1904, pp. 96-97; Siddons, 2009b, pp. 218-219). Contemporary depictions of the latter include the Donne Triptych by Hans Memling and numerous surviving effigies in churches (see Ward, 2016). In fact, churches with their mass audiences were well-suited to convey political messages, either implicitly through imagery or (more or less) explicitly through sermons and anonymous pamphlets.

\section{The function of badges}

The above discussion of major forms of display of the white rose of York in Edward IV's times, though admittedly cursory and incomplete, allows us to formulate certain general observations concerning the functioning of badges in late medieval England. ${ }^{11}$ Firstly, since badges were part of the heraldic system sensu largo, they likewise primarily utilised the visual channel of communication. Secondly, like coats of arms, they were emblematic; that is, they designated a person (see Hablot, 2017, p. 395; Ragen, 1994, p. 13). Yet reducing badges - or coats of arms, for that matter - to their referential function would not do justice to the motivations for their use. ${ }^{12}$ If their role had been to distinguish only, Edward IV would not have taken so much effort to display his numerous badges in various media, of which Free Library of Philadelphia MS Lewis E 201 is arguably the best illustration. The document in question is a pedigree roll, a popular genre among the royal and noble houses, which treated it as a tool for advertising their ancestry (see Sutton \& Visser-Fuchs, 1992; Radulescu, 2003). The fifteen-feet-long roll, compiled in the 1460s, presents seven lines of descent of the new king, justifying his claims to the crowns of England, France, Leon, and Castile, 


\section{Marcin Kudta}

and to the lordship of the whole of Britain and Ireland. The document is replete with Yorkist heraldic imagery: its margins are decorated with shields and banners carrying various coats of arms, each banner being held by one of Edward IV's badges, namely the white lion, the black bull, or the white hart. The spaces between the boxes containing the names of the king's ancestors are filled with 52 golden suns, 52 golden fetterlocks and 53 white and silver roses. ${ }^{13}$ Furthermore, 26 white roses are placed on the margins between the shields and banners. This repeated occurrence of the sun, rose, and fetterlock may be seen as a way of stressing Edward's connection to Richard II and to the Houses of Mortimer and York, respectively, from whom he derived the badges in question. Finally, in one place, the rose is combined with the York badge of the falcon and the fetterlock, so that the flower is placed inside while the bird sits on the fetterlock (Fig. 4). ${ }^{14}$

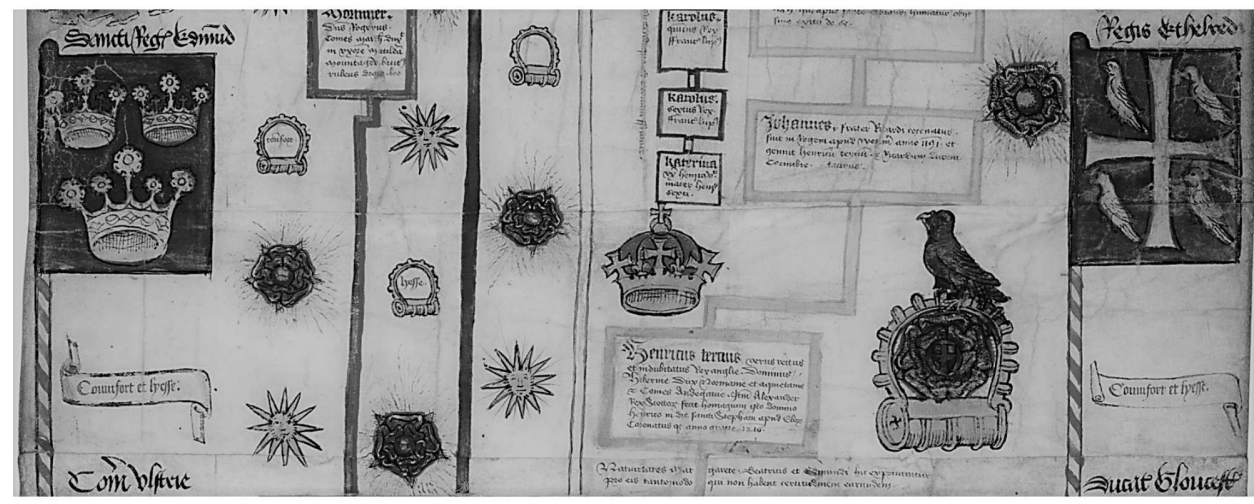

Figure 4. A fragment of FLP MS Lewis E 201 showing, among others, the alternating suns, fetterlocks and roses, as well as the combined badges of the rose, fetterlock and falcon (public domain)

It needs to be stressed that the rhetorical effectiveness of the use of badges in a pedigree roll and other media rested upon the assumption that the target audience would recognise the conceptual connection between the source and the target meaning, a connection that was metonymic. To be more specific, each badge formed a chain of associations rather than a single one, which in the case of the rose may be represented as follows:

White Rose $\rightarrow$ Edward IV $\rightarrow$ Richard of York $\rightarrow$ Mortimer $(\rightarrow \text { Lionel } \rightarrow \text { Edward III })^{15}$

As a matter of fact, each of the above chains allows for variant metonymic interpretations, since the name of a former owner of a badge can potentially stand for his or her prestige, might, rank, and/or approval of the current 
owner's actions. Still, the question remains whether Edward's contemporaries actually recognised the intended message. While it is impossible to verify this claim experimentally, some clues can be found in contemporary texts.

\section{Analysis}

Reference to heraldic badges is made in a number of contemporary political poems, many of which survive in fifteenth-century manuscripts reprinted, among others, in Madden (1842) and Robbins (1959). In particular, in a poem recounting the battle of Towton, around 26 badges are mentioned (as cited in Madden, 1842, pp. 343-347). They include "the Rose of Rone" 16 for Edward, ten badges for his major noble supporters, and fifteen badges represented on the banners of territorial or city levies. Nearly all examples invite a metonymic interpretation, in which the badge stands for its owner or soldiers fighting in a particular military unit. Yet, in the case of Edward, the message is more elaborate. This is evidenced by the fact that his badge is repeatedly mentioned throughout the text, twenty times occurring as "Rose" and sixteen times as "floure". ${ }^{17}$ Thus, Edward becomes the main protagonist of the poem and the whole narrative, except for the six stanzas that enumerate his allies' badges. More importantly, there are passages in which his badge is creatively exploited to achieve a particular rhetorical effect:

4 There sprange a Rose in Rone, and sprad into Englonde;

8 Blessid be $\mathrm{p}^{\mathrm{t}}$ Rose ryalle, that is so fresshe of hewe,

9 Almighty Jhesu blesse that soule, $\mathrm{p}^{\mathrm{t}}$ be sede sewe,

10 And blessid be pe gardeyne, per the Rose grewe;

As can be seen, the metonymic use of the badge for Edward interacts with the metaphorical representation of a family as a garden and offspring as a seed growing into a flower, which reinforces the pictorial metonymic use of heraldic badges on banners, pedigree rolls, etc. It might also be postulated that the passage makes use of the metaphorical mapping of the notions of FRESHNESS, YOUTHFULNESS and ATTRACTIVENESS ${ }^{18}$ from the domain FLOWER (and - especially in the latter case - ROSE) to the domain HUMAN BEING.

The latter metaphor is also visible in a poem which enumerates twelve letters which "shal saue all Inglonde" (as cited in Madden, 1842, pp. 330334 ), where one of the letters is: 
$49 \mathrm{R}$ for pe Rose, $\mathrm{p}^{\mathrm{t}}$ fresshe is in euery stede,

50 Bope pe rote and pe stalke ben gret of honoure,

Yet another poem for which similar imagery of the rose badge may be stipulated starts with "Awake, lordes" (as cited in Madden, 1842, pp. 340342). The author warns the Yorkists against the Lancastrian turncoats, who:

$5 \quad[\ldots]$ seyne in peire assemble, it is a wondre thyng,

6 To se be Rose in wyntre so fresshe for to spryng;

Here the possible timespan is even greater, ranging from 1457 to 1461 (see Robbins, 1959, p. 367; Hanham \& Cron, 2007, pp. 41-42). Hanham and Cron (2007, p. 42) forcefully argue for the latter date, in which case the above-quoted passage might refer both to Edward and to his father, killed in December 1460. That would not be inconsistent with the metaphor of a family as a garden and with the fact that Richard of York also used the rose badge during his lifetime (see Siddons, 2009b, p. 218).

It is impossible to state whether the texts and the metaphors included in them were created by one or more authors. Nor do we know how widespread the metaphorical interpretation of the rose badge was. They might have been originally written in one or more copies and distributed among Yorkist supporters or, as was the case with another poem, fixed to a church door (Davies, 1856, p. 91) in order to reach the general public. The very fact that they use rhyme can indicate that they were intended for oral transmission, although this claim cannot be proven.

There is one contemporary text, however, which can shed some light on the question of the popularity of the metaphorical interpretation of the white rose of York. It comes from a text known as Gregory's Chronicle (ed. by Gairdner, 1876), written down in the 1450s and 1460s probably by a resident of London (cf. Thomson, 1972). The passage in question records the reaction of Londoners on hearing that Edward, then still Earl of March, had defeated Lancastrian troops in Wales and was approaching the capital. According to the chronicler, the citizens

thonkyd God [...] and sayde, "Lette us walke in a newe wyne yerde, and lette us make us a gay gardon in the monythe of Marche with thys fayre whyte ros and herbe, the Erle of Marche" (as cited in Gairdner, 1876, p. 215).

Once again, the metaphor of a garden is employed. More importantly, it may be argued that the passage in question, even more than the above-mentioned poems, provides us with insights into the spoken language used by ordinary 
citizens, who apparently saw Edward IV's badge (and by analogy other badges) as more than just an emblem. ${ }^{19}$

\section{Discussion}

The above analysis raises questions concerning the semiotic status of badges, as well as the role of multimodality in the process of their interpretation. As far as the former is concerned, it might appear that when viewed from the perspective of heraldry as a semiotic system, badges might be seen as symbols conventionally taken to represent their owners. Yet in order to appreciate their role in the medieval world, a more nuanced view is necessary. Taking the Peircean model as the point of departure, it is assumed here that semiosis is a psychological process (Peirce, 1934, 5.484). Consequently, the right question is not which type of sign badges belonged to, but which type a particular badge represented to a particular sign-user. Thus, it may be assumed that for those who were not familiar with Edward IV's motivation behind the choice of the white rose, the badge in question might have been a symbol, while to others, especially the inhabitants of the Welsh Marches, it was an index of his father or his Mortimer ancestors. Yet others, whether they knew the Mortimer connection or not, noticed a metaphorical (or iconic) link between the badge and Edward IV's traits and political status.

Addressing the second question, it can be observed that while most forms of expression of heraldry employed the visual channel, the ubiquity of language as a tool for communication meant that coats of arms and badges were expressed and elaborated on in this semiotic system as well. The examples analysed above can be ascribed to two major metaphors: A FAMILY IS A GARDEN (which involves the mapping A YOUTHFUL/ENERGETIC FAMILY MEMBER IS A FLOWER) and AN ATTRACTIVE PERSON IS A ROSE. At first glance, the examples analysed above appear to be monomodal, since both the target and the source are expressed verbally. Yet Edward's contemporaries perceived those metaphorical readings in the broad context of his use of the white rose as an heraldic badge. Thus, it may be argued that the whole forms a multimodal mataphtonymy of the metonymy-within-metaphor type (cf. Goossens, 1990, pp. 334-335), in which the target of the metaphors (that is, Edward IV) is accessed via the conventional or "sleeping", metonymy BADGE FOR OWNER. The metaphors themselves, in turn, while undoubtedly based on well-established associations, were employed in this context in a novel way, which rendered them "waking" (cf. Müller, 2008). 


\section{Conclusions}

The above analysis has shown that the proper interpretation of the reference to heraldic badges in language is possible only against the predominantly (although not exclusively) visual background of their occurrence. Or, to put it differently, we can conclude that the natural environment of badges is inherently multimodal, even if particular instances turn out to be monomodal. It has also demonstrated that just as non-verbal clues can help interpret verbal messages (see Müller, 2008), the reverse is also possible. This is especially important in the context of historical research, which presents obvious difficulties for a modern scholar.

Nevertheless, it must be stressed that the issue of heraldic badges still remains an underexplored field that deserves more systematic and comprehensive semiotic research.

\section{N O T E S}

1 The author would like to thank the reviewers for their constructive and inspirational remarks.

${ }^{2}$ It was perceived as such by the authors of a number of medieval heraldic treatises (see Dennys, 1975, pp. 65, 68).

3 See, for example, the Wilton Diptych, in which both Richard II and each of the angels wear a brooch in the form of the white heart, the king's badge.

4 The best example here is the modification of Edward III's coat of arms following the outbreak of the Hundred Years War: in order to stress his claim to the French throne, Edward III quartered the three leopards of England with the fleur-de-lis of France (London, 1956, p. 27). It was not until 1801, long after the English kings had renounced the claim, that the French quarter was removed from the official coat of arms of the then British sovereign (see Friar \& Ferguson, 1993, p. 38).

${ }^{5}$ Fox-Davies (1907, p. 61) acknowledges the growing complexity of coats of arms as a factor in the development of badges, yet he links it to the alleged lack of heraldic experience on the part of the uneducated masses. The modern view of a medieval society as "heraldically literate" belies such a judgement. The merits of a simpler design that the badge offered were of a pragmatic nature: apart from their usefulness as identification signs in battle (see also Jones, 2010, p. 62), they were also easier to produce in different media.

6 See also the above-mentioned Hablot (2006), who focuses on badges used in late medieval France and Burgundy.

7 Siddons (2009b, p. 211) relates the Clifford connection to the second wife of Richard, earl of Cambridge, Maud (d. 1446). However, in her will she makes no mention of her stepson, Richard of York, or any of his siblings (Raine, 1855, pp. 118-124). When his father died in 1415, Richard was four years old. He became a ward of the crown and his wardship was granted to Ralph Nevill, first earl of Westmoreland, whose daughter, Cecily, the duke of York eventually married (Griffiths, 1981, p. 85). It is doubtful, therefore, that Richard would have sported a badge inherited from his step-mother, for whom he apparently felt little affection. 
8 The available data do not allow to ascertain whether the choice of the colour of the badge in question was in any way determined by the qualities that contemporary heraldic treatises ascribed to silver (which was the intended heraldic colour represented by white), namely PURITY, JUSTICE or MOON (see Dennys, 1975, p. 46).

${ }^{9}$ A fetterlock was a device for curbing the legs of a horse.

10 It is not certain whether Edward IV chose this particular badge of Richard II because of its Christian and pre-Christian divine associations, or because of the occurrence of the "three suns" before his victorious battle at the Mortimer's Cross (see Gairdner, 1876, p. 211), or - which is also possible - because of the aesthetic appeal of the arrangement of the two badges.

11 Admittedly, most nobles had neither the ambitions nor means of Edward IV, which raises the question of the representativeness of the data. Yet the real difference is that of scale; noble badges during the period under consideration occurred in all of the media described above, though hardly any of them occurred in all of the media.

12 Admittedly, Hablot (2017, pp. 395-396) does acknowledge what he calls "symbolic" - in the Saussurean, rather than Peircean sense of the term - aspects of emblems. See below for a further discussion of this problem.

13 Due to the process of oxidization, the silver roses had turned black.

14 There is no information on how MS Lewis E 201 and similar pedigree rolls were used, but it was probably too precious and too detailed to be made available for the public eye. It is more likely that it formed part of Edward IV's library and was reserved for the use of the king, his family and guests. Yet some of the more image-dominated examples might have been displayed in churches (Sutton \& Visser-Fuchs, 1992, p. 346). A more detailed description of the document may be found in Scott (1996, pp. 288-289).

15 Names in brackets denote members of the royal family who did not use the badges in question, yet to whom Edward IV's lines of descent ultimately lead.

16 "Rone" is Rouen, Edward's birthplace.

17 Each of the sixteen stanzas ends with a chorus: "Blessid be be tyme $\mathrm{p}^{\mathrm{t}}$ euer God spred $\mathrm{p}^{\mathrm{t}}$ floure", or its variant.

18 The rose had been associated with love, beauty and passion since ancient times and this link was exploited also in medieval Europe (see e.g. Touw, 1982). Edward, who was only eighteen years old when he seized the crown, was perceived as handsome by his contemporaries (see Philippe de Commynes' memoirs as cited in Belin, 1843, p. 126). There were obviously other meanings ascribed by medieval people to the rose in general and the white rose in particular, such as CHASTITY, yet there are no sources which would suggest this connection in the case of Edward IV.

19 Theoretically, it is possible that the quotation is merely a piece of propaganda, yet this is not very likely. While the author of the chronicle is not completely impartial, there are places in which he is critical of the Yorkists and sympathetic towards the Lancastrians, which adds to his reliability (see Gairdner, 1876, pp. 208-209, 211).

\section{S O U R C E M A T E R I A L}

Memling, Hans (c. 1475). The Donne Triptych [Painting]. London: The National Gallery. Retrieved from https://www.nationalgallery.org.uk/paintings/hansmemling-the-donne-triptych 
MS Lewis E 201. Philadelphia: Free Library of Philadelphia. Retrieved from http:// openn.library.upenn.edu/Data/0023/html/lewis_e_201.html

\section{R E F E R E N C E S}

Ailes, A. (2002). Heraldry in medieval England: Symbols of politics and propaganda. In P. S. Coss \& M. Keen (Eds.), Heraldry, pageantry and social display in medieval England (pp. 83-104). Woodbridge, England: Boydell Press.

Archer, T. A. (1887). Clifford, Walter de. In L. Stephen (Ed.) Dictionary of national biography, volume 1 (pp. 81-82). London: Smith, Elder \& Co.

Backhouse, J. (1999). The Royal Library from Edward IV to Henry VII. In L. Hellinga \& J. B. Trapp (Eds.) The Cambridge history of the book in Britain, volume III: 1400-1557 (pp. 267-273). Cambridge: Cambridge University Press.

Bateman, J., Wildfeuer, J., \& Hiippala, T. (2017). Multimodality. Berlin and Boston: Mouton de Gruyter.

Belin, J. J. (Ed.). (1843). Mémoires de Commines. Paris: Belin.

Birch, W. (1887). Catalogue of seals in the Department of Manuscripts in the British Museum, volume I. London: William Clowes \& Sons.

Blair, C., \& Delamer, I. (1988). The Dublin civic swords. Proceedings of the Royal Irish Academy: Archaeology, Culture, History, Literature, 88, 87-142.

Boutell, C. (1864). Heraldry, historical and popular. London: Richard Bentley.

Cienki, A. (2013). Conceptual metaphor theory in light of research on gesture with speech. Cognitive Semiotics 5(1-2), 349-366.

Coss, P. S., \& Keen, M. (2002). Heraldry, pageantry and social display in medieval England. Woodbridge, England: Boydell Press.

Davies, J. S. (Ed.). (1856). An English chronicle of the reigns of Richard II, Henry IV, Henry V, and Henry VI written before the year 1471. London: Camden Society.

Dennys, R. (1975). Heraldic imagination. London: Barrie \& Jenkins.

Dirven, R., \& Pörings, R. (Eds.) (2002) Metaphor and metonymy in comparison and contrast. Berlin: Mouton de Gruyter.

Ellis, H. (1814). Enumeration and explanation of the devices formerly borne as badges of cognizance by the House of York. Archaeologia, 17, 226-227.

Fauconnier, G., \& Turner, M. (1995). Conceptual integration and formal expression. Journal of Metaphor and Symbolic Activity, 10, 183-204.

Fauconnier, G., \& Turner, M. (2002). The way we think: Conceptual blending and the mind's hidden complexities. New York: Basic Books. 
Forceville, C. (2010). Why and how study metaphor, metonymy, and other tropes in multimodal discourse? In A. S. da Silva, J. C. Martins, L. Magalhaes \& M. Goncalves (Eds.), Comunicação, Cognição e Media (pp. 41-60). Braga, Portugal: Universidade Católica Portuguesa.

Forceville, C., \& Urios-Aparisi, E. (Eds.). (2009). Multimodal metaphor. Berlin and New York: Mouton de Gruyter.

Fox-Davies, A. C. (1907). Heraldic badges. London: John Lane.

Friar, S., \& Ferguson, J. (1993). Basic heraldry. London: The Herbert Press.

Gairdner, J. (Ed.). (1876). The historical collections of a citizen of London in the fifteenth century. London: Camden Society.

Gairdner, J. (Ed.). (1904). The Paston letters A.D. 1422-1509, volume V. London: Chatto \& Windus.

Geeraerts, D. (2010). Theories of lexical semantics. Oxford: Oxford University Press.

Geeraerts, D., \& Cuyckens, H. (2007). Introducing cognitive linguistics. In D. Geeraerts \& H. Cuyckens (Eds.), The Oxford handbook of cognitive linguistics (pp. 3-21). Oxford: Oxford University Press.

Goossens, L. (1990). Metaphtonymy: The interaction of metaphor and metonymy in expressions for linguistic actions. Cognitive Linguistics, 1, 323-340.

Griffiths, R. A. (1981). The reign of king Henry VI: The exercise of royal authority, 1422-1461. Berkeley and Los Angeles: University of California Press.

Hablot, L. (2006). La devise, un nouvel emblème pour les princes du xve siècle, la création artistique en France autour de 1400. In. É. Taburet-Delahaye (Ed.), Actes du colloque international École du Louvre-Musée des BeauxArts de Dijon-Université de Bourgogne, École du Louvre, 7 et 8 juillet 2004, Musée des Beaux-Arts de Dijon-Université de Bourgogne, 9 et 10 juillet 2004 (pp. 177-192). Paris: École du Louvre.

Hablot, L. (2017). Heraldic imagery, definition, and principles. In C. Hourihane (Ed.), The Routledge companion to medieval iconography (pp. 386-398). London: Routledge.

Hammond, P. W., Sutton, A. F., \& Visser-Fuchs, L. (1994). The reburial of Richard, duke of York, 21-30 July 1476. Ricardian, 10, 122-165.

Hanham, A., \& Cron, B. M. (2007). Slain dogs, the dead man and editorial constructs. Ricardian, 17, 33-54.

Hiltmann, T. (2018). Arms and art in the Middle Ages. In T. Hiltmann \& L. Hablot (Eds.), Heraldic artists and painters in the Middle Ages and early modern times (pp. 11-23). Ostfildern, Germany: Thorbecke.

Hiltmann, T., \& Hablot, L. (Eds.). (2018). Heraldic artists and painters in the Middle Ages and early modern times. Ostfildern, Germany: Thorbecke.

Jewitt, C., Bezemer, J., \& O'Halloran, K. (2016). Introducing multimodality. Routledge: London. 
Jones, R. W. (2010). Bloodied banners: Martial display on the medieval battlefield. Woodbridge, England: Boydell Press.

Kolter, A., Ladewig, S. H., Summa, M., Müller, C., Koch, S. C., \& Fuchs, T. (2012). Body memory and the emergence of metaphor in movement and speech: An interdisciplinary case study. In S. C. Koch, T. Fuchs, M. Summa \& C. Müller (Eds.), Body memory, metaphor and movement (pp. 201-226). Amsterdam: John Benjamins.

Kövecses, Z. (2010). A new look at metaphorical creativity in cognitive linguistics. Cognitive Linguistics, 21(4), 655-689.

Lakoff, G., \& Johnson, M. (1980). Metaphors we live by. Chicago: University of Chicago Press.

Lakoff, G., \& Turner, M. (1989). More than cool reason: A field guide to poetic metaphor. Chicago: University of Chicago Press.

Langacker, R. W. (1993). Reference-point constructions. Cognitive Linguistics, 4, $1-38$.

London, H. S. (1956). Royal beasts. East Knoyle, England: The Heraldry Society.

Madden, F. (Ed.). (1842). Political poems of the reigns of Henry VI and Edward IV. Archaeologia, 29, 318-347.

Müller, C. (2008). Metaphors dead and alive, sleeping and waking: A dynamic view. Chicago: University of Chicago Press.

Nerlich, B., \& Clarke, D. D. (2007). Cognitive linguistics and the history of linguistics. In D. Geeraerts \& H. Cuyckens (Eds.), The Oxford handbook of cognitive linguistics (pp. 589-607). Oxford: Oxford University Press.

Nichols, J. (Ed.). (1780). A collection of all the wills, now known to be extant, of the kings and queens of England, princes and princesses of Wales, and every branch of the blood royal, from the reign of William the Conqueror to that of Henry the Seventh. London: John Nichols.

Panther, K.-U., \& Radden, G. (Eds.). (1999). Metonymy in language and thought. Amsterdam: John Benjamins.

Pastoureau, M. (1993). Traité d'héraldique. Paris: Picard.

Pastoureau, M. (2004). Une histoire symbolique du Moyen Âge occidental. Paris: Éditions de Seuil.

Peirce, C. S. (1934). A survey of pragmaticism. In C. Hartshorne \& P. Weiss. (Eds.), The collected papers of Charles Sanders Peirce, volume V: Pragmatism and pragmaticism (pp. 464-496). Cambridge: Harvard University Press.

Radulescu, R. (2003). Yorkist propaganda and 'The chronicle from Rollo to Edward IV'. Studies in Philology, 100(4), 401-424.

Ragen, B. A. (Ed.). (1994). Semiotics and heraldry. Semiotica, 100(1), 5-34.

Raine, J. (1855). Testamenta eboracensia: A selection of wills from the registry at York. Part II. London: Surtees Society.

Rickard, J. (2002). The castle community: The personnel of English and Welsh castles, 1272-1422. Woodbridge, England: Boydell Press. 
Robbins, R. H. (Ed.). (1959). Historical poems of the 14th and 15th centuries. New York: Columbia University Press.

Rothery, G. C. ([1915]1985). Concise encyclopedia of heraldry. London: Bracken Books.

Scott, K. L. (1996). Later gothic manuscripts, 1390-1490. London: Harvey Miller.

Siddons, M. P. (2009a). Heraldic badges in England and Wales. Volume I: Introduction. Woodbridge: Boydell Press.

Siddons, M. P. (2009b). Heraldic badges in England and Wales. Volume II, part 1: Royal badges. Woodbridge: Boydell Press.

Siddons, M. P. (2009c). Heraldic badges in England and Wales: Volume II, part 2: Non-royal badges. Woodbridge: Boydell Press.

Siddons, M. P. (2009d). Heraldic badges in England and Wales. Volume III: Ordinaries. Woodbridge: Boydell Press.

Sutton, A. F., \& Visser-Fuchs, L. (1992). Richard III's books: Ancestry and 'true nobility'. Ricardian, 119(9), 343-358.

Touw, M. (1982) Roses in the Middle Ages. Economic Botany, 36(1), 71-83.

Tseronis, A., \& Forceville, C. (2009). Introduction. In A. Tseronis \& C. Forceville (Eds.), Multimodal argumentation and rhetoric in media genres (pp. 1-24). Amsterdam: John Benjamins.

Wagner, A. R. (1955). The swan badge and the Swan Knight. Archaeologia, 97, $127-138$.

Wagner, A. R. (1972). Historic heraldry of Britain. London: Pillimore.

Ward, M. (2016). The livery collar in late medieval England and Wales: Politics, identity and affinity. Woodbridge, England: Boydell Press. 